\title{
Assessment of Chemical Properties of Soil from Different Blocks of Buldana District Maharashtra
}

\author{
Panherkar Ujjwal*, Tarence Thomas and Arun A. David \\ Department of Soil Science and Agricultural Chemistry, Naini Agricultural Institute \\ Sam Higginbottom University of Agriculture, Technology and Sciences, \\ Prayagraj-211007, U.P., India \\ *Corresponding author
}

\section{A B S T R A C T}

K e y w o r d s
Physico-chemical
properties of soil,
Buldana, Nitrogen,
Phosphorus,
Potassium
etc.
Article Info
Accepted:
22 October 2020
Available Online:
10 November 2020

The soil samples were collected from three blocks of the Buldana district from two depth viz. 0-15 cm and 15-30 cm for the assessment of the chemical properties of soil of Buldana district, Maharashtra was carried out in 2019-20. Eighteen sampling points in different villages were selected for the analysis. The colour of soil changed between the two depths of 0-15 and $15-30 \mathrm{~cm}$ at all the locations. There was also difference in colour of dry and wet soils were dark greyish brown to black. The study revealed that range of particle density was from 2.15 to $2.55 \mathrm{Mgm}^{-3}$, bulk density from 1.09 to $1.19 \mathrm{Mgm}^{-3}$, water holding capacity from $57.14 \%$ to $91.89 \%$. The sand, silt and clay ranges were from $19-23 \%, 32-$ $40 \%$ and $41-48 \%$ respectively. It includes mean highest percent pore space 61.11 and the lowest percent pore space 51.94. The $\mathrm{pH}$ ranges from 6.67 to 8.29 . The EC ranges from 0.17 to $0.63 \mathrm{dSm}^{-1}$. The organic carbon ranges from 0.26 to $0.92 \%$, \& organic matter ranges from 0.31 to $1.57 \%$,nitrogen ranges from 114.24 to $409.52 \mathrm{~kg} \mathrm{ha}^{-1}$, phosphorus ranges from 12.49 to $28.31 \mathrm{~kg} \mathrm{ha}^{-1}$, potassium ranges from 120 to $320.2 \mathrm{~kg} \mathrm{ha}^{-1}$, calcium ranges from 0.32 to $0.42\left(\mathrm{mgg}^{-1}\right)$, magnesium ranges from 7.90 to $10.25\left(\mathrm{mgm}^{-1}\right)$, iron ranges from 1.6 to $5.33(\mathrm{ppm})$, zinc ranges from 0.10 to1.54 (ppm) and copper ranges from 0.51 to 1.51 (ppm).

\section{Introduction}

Soil is a vital resource, can be termed as 'Soul of infinite life'. The essence of life in the soil is its crop producing capacity i.e. the soil productivity largely depends on soil fertility, management practices and climate. These agricultural practices can be managed, while the climate is natural factor which influences the soil fertility. Therefore, soil fertility is the major component of productivity which primarily deals with nutrient supplying capacity of the soil to the plant. Therefore, it has been always considered to carry out genetic study as well as to find out fertility evaluation for making best use of the soil for crop production. Ensuring food security for the ever-increasing world population has 
direct relation with physicochemical property, fertility and productivity of soil. The overall productivity and sustainability of a given agricultural sector is highly dependent up on the fertility and physicochemical characteristics of soil resources (Priyanka et al., 2018). Chemical characteristics of different soils vary in space and time due to variation in topography, climate, physical weathering processes, vegetation cover, microbial activities, and several other biotic and abiotic variables (Tale et al., 2015).

\section{Soil health indicators}

The quality of soil is rather dynamic and can affect the sustainability and productivity of land use. It is the end product of soil degradative or conserving processes and is controlled by chemical, physical and biological components of a soil and their interactions (Papendick and Parr, 1992). The chemical properties of the soil are the interactions of various chemical constituents among soil particles and the soil solution. These physical and chemical properties are soil texture, bulk density particle density water holding capacity, soil structure, soil colour, $\mathrm{pH}$, electrical conductivity, cation exchange capacity, organic carbon, organic matter and soil nutrients (divided as macro and micro nutrient)(Nirmal, 2015).

\section{Materials and Methods}

The present study entitled "Assessment of physico-chemical Properties of Soil from different blocks of Buldana District of Maharashtra" was carried out during 2019-20 in three stages (Table 1). Soil survey and mapping, collection of samples and their analysis for different soil parameters. The samples were collected periodically from the selected sites at the same time in the kharif season. (Rice, Maize, Soybean, Cowpea etccrop) grown in this season. Soil samples have been collected at a depth of $0-15 \mathrm{~cm}$ and $15-30 \mathrm{~cm}$ at the site. Samples have been collected only from the open places. Sampling dates have been selected in such a way that these represent the major seasons of the year viz. autumn, winter, spring, dry summer, and wet summer. Separate sampling calendar has been made for each parameter to be studied. Some of the chemical characteristics like temperature, $\mathrm{pH}$ and conductivity have been determined. Soil chemical and physical characteristics of some of the soils of different regions are discussed below (Table 2).

\section{Soil sampling}

Soil samples were collected from the three different blocks of Buldana district Maharashtra. They are Jalgaon Jamod, Sangrampur and Nandura. Soil samples were collected with the help of Khurpi, Spade and meter scale. In each block, three village selected for sampling and samples obtained from two different depths $0-15 \mathrm{~cm}$ and 15-30 $\mathrm{cm}$, totally eighteen soil sample were collected.

\section{Results and Discussion}

As presented in table 3 and fig. 1, the highest soil pH $7.82<7.67$ lowest 6.67 were recorded in villages Vadshingi, Borala and minimum Yerali respectively, at $0-15 \mathrm{~cm}$ depth and at $15-30 \mathrm{~cm}$ maximum $\mathrm{pH} 8.21<7.80$ lowest 7.20 were recorded Vadshingi, Borala and lowest Dahivadi, due to depth and sitesEC was found to be significant, and the highest soilEC $0.67<0.18$ lowest 0.17 were recorded in villages Nimbhora, Rudhana and minimum vadshingi respectively, at $0-15 \mathrm{~cm}$ depth and at $15-30 \mathrm{~cm}$ maximum EC0.70< 0.21 lowest 0.19 were recorded Nimbhora, Rudhana and lowest Vadshingi, due to depth and sites $\mathrm{pH}$ was found to be significant, Irrigating in amounts too low to leach salts, or with water high in salts, allows salts to accumulate in the 
root zone, increasing EC. Similar results were reported by Dhamak et al., (2014).

As presented in table 4 and fig. 2, the highest soil organic carbon $0.92<0.56$ lowest 0.26 were recorded in villages Nimgaon and minimum Rudhana respectively, at $0-15 \mathrm{~cm}$ depth and at $15-30 \mathrm{~cm}$ maximum organic carbon $0.80<0.45$ lowest 0.18 were recorded Borala, Nimgaon and lowest Rudhana, due to depth and sites and organic carbon was found to be significant. Increasing the proportion of perennial species in pastures will increase organic carbon in soils Similar results were reported by Priyanka et al., (2018) and the highest soil O.M1.58< 0.96 lowest 0.44 were recorded in villages Borala, Nimgaon and minimum Rudhana respectively, at $0-15 \mathrm{~cm}$ depth and at 15-30 cm maximum O.M1.37< 0.77 lowest 0.31 were recorded Borala, Nimgaon and lowest Rudhana, due to depth and sites O.M was found to be significant, increase the FYM dose soil organic carbon are maintain, similar results were reported by Brij et al., (2016).
As presented in table 5 and fig. 3, the highest soil available nitrogen $0.92<0.56$ lowest 0.26 were recorded in villages Nimgaon, and minimum Rudhana respectively, at $0-15 \mathrm{~cm}$ depth and at $15-30 \mathrm{~cm}$ maximum available nitrogen $0.80<0.45$ lowest 0.18 were recorded Borala, Nimgaon and lowest Rudhana, due to depth and sites and available nitrogen was found to be significant. the high contain of organic matter increase the level of nitrogen, Similar results were reported by Brij et al., (2016). and the highest soil O.M $1.58<$ 0.96 lowest 0.44 were recorded in villages Borala, Nimgaon and minimum Rudhana respectively, at $0-15 \mathrm{~cm}$ depth and at $15-30$ cm maximum O.M $1.37<0.77$ lowest 0.31 were recorded Borala, Nimgaon and lowest Rudhana, due to depth and sites O.M was found to be significant, Phosphorus buildup is caused by excessive use of inorganic fertilizer or the use of composts and manures high in phosphorus. High soil phosphorus levels also can threaten streams, rivers, lakes and oceans. Similar results were reported by Ganorkar et al., (2013).

Table.1 The entire study area has been divided into three major regions

\begin{tabular}{|c|l|l|c|c|}
\hline S. No. & Block (Tehsil) & Village & Latitude $\left({ }^{\mathbf{0}} \mathbf{N}\right)$ & Longitude $\left.\mathbf{(}^{\mathbf{0}} \mathbf{E}\right)$ \\
\hline $\mathbf{0 1}$ & Jalgaon jamod & 1. Borala & 76.592025 & 21.014672 \\
\hline & & 2. Nimbhora & 21.042323 & 76.564807 \\
\hline & & 3. Wadshingi & 21.010847 & 76.610408 \\
\hline $\mathbf{0 2}$ & Sangrampur & 1. Rudhana & 20.580300 & 76.215450 \\
\hline & & 2. Vakana & 20.536560 & 76.180490 \\
\hline & & 3. Warwat & 21.034139 & 76.682293 \\
\hline $\mathbf{0 3}$ & Nandura & 1. Nimgaon & 20.827417 & 76.459336 \\
\hline & & 2. Yerali & 20.928619 & 76.476216 \\
\hline & & 3. Dahivadi & 17.623163 & 74.529834 \\
\hline
\end{tabular}


Table.2 Soil chemical properties and their respective methods for analysis

\begin{tabular}{|c|c|c|c|c|}
\hline S. No. & Parameters & Unit & Methodology & Author's \\
\hline 1. & Soil pH (1:2) & - & Digital pH Meter & Jackson, 1958 \\
\hline 2. & $\begin{array}{l}\text { Electrical } \\
\text { conductivity }(1: 2)\end{array}$ & $\mathrm{dS} \mathrm{m}^{-1}$ & $\begin{array}{l}\text { Digital Conductivity } \\
\text { Meter }\end{array}$ & Wilcox, 1950 \\
\hline 3. & Organic carbon & $\%$ & Rapid titration & Walkley, 1947 \\
\hline 4. & Organic matter & $\%$ & $\% \mathrm{OM}=\% \mathrm{OC} \times 1.724$ & Van Bemmelen Factor \\
\hline 5. & Available nitrogen & $\mathrm{kg} \mathrm{ha}^{-1}$ & $\begin{array}{l}\text { Alkaline potassium } \\
\text { permanganate }\end{array}$ & Subbiah and Asija, 1956 \\
\hline 6. & Available phosphorus & $\mathrm{kg} \mathrm{ha}^{-1}$ & Spectrophotometric & Olsen et al., 1954 \\
\hline 7. & Available potassium & $\mathrm{kg} \mathrm{ha}^{-1}$ & Flame Photometric & Toth and Prince, 1949 \\
\hline 8. & $\begin{array}{l}\text { Exchangeable } \\
\text { calcium and } \\
\text { magnesium }\end{array}$ & $\begin{array}{l}\text { Cmol } \\
(p+) \mathrm{kg}^{-1}\end{array}$ & $\begin{array}{l}\text { 1N Neutral ammonium } \\
\text { acetate saturation /EDTA }\end{array}$ & Cheng and Bray, 1951 \\
\hline 9. & Available Sulphur & ppm & Turbidimetric & Chesnin andYien, 1950 \\
\hline
\end{tabular}

Table.3 Assessment Soil pH (: $2.5 \mathrm{w} / \mathrm{v})$ and $\mathrm{EC}\left(\mathrm{dS} \mathrm{m}^{-1}\right)$ at 0-15 and 15-30 $\mathrm{cm}$ depths of farmer's field in Buldana district of Maharashtra

\begin{tabular}{|c|c|c|c|c|c|c|}
\hline \multirow[t]{2}{*}{ Villages } & \multicolumn{3}{|c|}{ Soil pH } & \multicolumn{3}{|c|}{ Soil EC $\left(\mathbf{d S} \mathbf{m}^{-1}\right)$} \\
\hline & $0-15 \mathrm{~cm}$ & $15-30 \mathrm{~cm}$ & & $0-15 \mathrm{~cm}$ & $15-30 \mathrm{~cm}$ & \\
\hline Borala & 7.67 & 7.80 & & 0.51 & 0.63 & \\
\hline Vadshingi & 7.82 & 8.21 & & 0.17 & 0.19 & \\
\hline Nimbhora & 7.52 & 7.72 & & 0.67 & 0.70 & \\
\hline Nimgaon & 7.50 & 7.62 & & 0.36 & 0.50 & \\
\hline Dahivadi & 7.05 & 7.20 & & 0.43 & 0.55 & \\
\hline Yerali & 6.67 & 7.00 & & 0.34 & 0.52 & \\
\hline Vakana & 7.58 & 7.68 & & 0.51 & 0.60 & \\
\hline Rudhana & 7.36 & 7.48 & & 0.18 & 0.21 & \\
\hline Warwat & 7.21 & 7.50 & & 0.20 & 0.25 & \\
\hline Mean & 7.48 & 7.58 & & 0.374 & 0.461 & \\
\hline & F-TEST & $\operatorname{S.ED}( \pm)$ & C.D@0.05\% & F-TEST & S.ED(+-) & C.D@0.05\% \\
\hline Due to depth & $\mathbf{S}$ & 0.150064 & 0.00098 & S & 0.061283 & 0.001848 \\
\hline Due to site & $\mathbf{S}$ & 0.354507 & 2.806605 & $\mathbf{S}$ & 0.181058 & 1.13205 \\
\hline
\end{tabular}


Table.4 Assessment of organic carbon (\%) and organic matter (\%) of farmers field at 0-15 and 15-30 cm depth in Buldana district of Maharashtra

\begin{tabular}{|l|c|c|c|c|c|c|}
\hline \multicolumn{1}{|c|}{ Villages } & \multicolumn{3}{|c|}{ Organic carbon (\%) } & \multicolumn{3}{c|}{ Organic matter (\%) } \\
\hline & $0-15 \mathrm{~cm}$ & $15-30 \mathrm{~cm}$ & & $0-15 \mathrm{~cm}$ & $15-30 \mathrm{~cm}$ & \\
\hline Borala & 0.92 & 0.80 & & 1.58 & 1.37 & \\
\hline Vadshingi & 0.42 & 0.30 & & 0.72 & 0.51 & \\
\hline Nimbhora & 0.38 & 0.30 & & 0.65 & 0.51 & \\
\hline Nimgaon & 0.56 & 0.45 & & 0.96 & 0.77 & \\
\hline Dahivadi & 0.42 & 0.35 & & 0.72 & 0.60 & \\
\hline Yerali & 0.56 & 0.35 & & 0.98 & 0.60 & \\
\hline Vakana & 0.35 & 0.20 & & 0.60 & 0.34 & \\
\hline Rudhana & 0.26 & 0.18 & & 0.44 & 0.31 & \\
\hline Warwat & 0.35 & 0.22 & & 0.58 & 0.37 & \\
\hline Mean & 0.47 & 0.35 & & 0.80 & 0.59 & \\
\hline & F-TEST & S.ED $( \pm)$ & C.D@0.05\% & F-TEST & S.ED $( \pm)$ & C.D @0.05\% \\
\hline Due to & S & 0.084853 & 4.980605 & S & 0.14535 & 5.63605 \\
dept & & & & & & \\
\hline Due to site & S & 0.19105 & 1.370607 & S & 0.329455 & 1.48606 \\
\hline
\end{tabular}

Table.5 Assessment of available nitrogen and phosphorus $\left(\mathrm{kg} \mathrm{ha}^{-1}\right)$ in farmer's field at 0-15 and $15-30 \mathrm{~cm}$ depth in Buldana district of Maharashtra

\begin{tabular}{|c|c|c|c|c|c|c|}
\hline \multirow[t]{2}{*}{ Villages } & \multicolumn{3}{|c|}{ Available nitrogen $\left(\mathrm{kg} \mathrm{ha}^{-1}\right)$} & \multicolumn{3}{|c|}{ Available phosphorus ( $\left.\mathrm{kg} \mathrm{ha}^{-1}\right)$} \\
\hline & $0-15 \mathrm{~cm}$ & $15-30 \mathrm{~cm}$ & & $0-15 \mathrm{~cm}$ & $15-30 \mathrm{~cm}$ & \\
\hline Borala & 409.52 & 360.09 & & 14.69 & 12.11 & \\
\hline Vadshingi & 188.16 & 160.00 & & 19.73 & 15.73 & \\
\hline Nimbhora & 168.00 & 150.20 & & 28.31 & 22.11 & \\
\hline Nimgaon & 248.64 & 220.10 & & 14.69 & 12.59 & \\
\hline Dahivadi & 188.16 & 172.00 & & 16.00 & 14.11 & \\
\hline Yerali & 255.36 & 220.11 & & 12.49 & 10.42 & \\
\hline Vakana & 154.50 & 130.50 & & 16.88 & 15.97 & \\
\hline Rudhana & 114.24 & 100.24 & & 16.22 & 12.14 & \\
\hline Warwat & 154.56 & 151.56 & & 12.28 & 10.28 & \\
\hline \multirow[t]{2}{*}{ Mean } & 209.015 & 184.977 & & 16.7988 & 14.02 & \\
\hline & FTEST & $\operatorname{S.ED}( \pm)$ & C.D@0.05\% & F-TEST & $\operatorname{S.ED}( \pm)$ & C.D@0.05\% \\
\hline Due to depth & S & 17.0287 & 0.000707 & S & 2.029396 & 0.000684 \\
\hline Due to site & $\mathbf{S}$ & 81.8593 & 7.45608 & $\mathbf{S}$ & 4.24194 & 4.67605 \\
\hline
\end{tabular}


Table.6 Assessment of available potassium $\left(\mathrm{kg} \mathrm{ha}^{-1}\right)$ and Calcium $\left(\mathrm{mgg}^{-1}\right)$ in farmer's field at 0-15 and $15-30 \mathrm{~cm}$ depth in Buldana district of Maharashtra

\begin{tabular}{|c|c|c|c|c|c|c|}
\hline \multirow[t]{2}{*}{ Villages } & \multicolumn{3}{|c|}{ Available nitrogen $\left(\mathrm{kg} \mathrm{ha}^{-1}\right)$} & \multicolumn{3}{|c|}{ Available phosphorus (kg ha $\left.{ }^{-1}\right)$} \\
\hline & $0-15 \mathrm{~cm}$ & $15-30 \mathrm{~cm}$ & & $0-15 \mathrm{~cm}$ & $15-30 \mathrm{~cm}$ & \\
\hline Borala & 409.52 & 360.09 & & 14.69 & 12.11 & \\
\hline Vadshingi & 188.16 & 160.00 & & 19.73 & 15.73 & \\
\hline Nimbhora & 168.00 & 150.20 & & 28.31 & 22.11 & \\
\hline Nimgaon & 248.64 & 220.10 & & 14.69 & 12.59 & \\
\hline Dahivadi & 188.16 & 172.00 & & 16.00 & 14.11 & \\
\hline Yerali & 255.36 & 220.11 & & 12.49 & 10.42 & \\
\hline Vakana & 154.50 & 130.50 & & 16.88 & 15.97 & \\
\hline Rudhana & 114.24 & 100.24 & & 16.22 & 12.14 & \\
\hline Warwat & 154.56 & 151.56 & & 12.28 & 10.28 & \\
\hline \multirow[t]{2}{*}{ Mean } & 209.015 & 184.977 & & 16.7988 & 14.02 & \\
\hline & FTEST & $\operatorname{S.ED}( \pm)$ & C.D@0.05\% & F-TEST & $\mathbf{S . E D}( \pm)$ & C.D@0.05\% \\
\hline Due to depth & $\mathbf{S}$ & 17.0287 & 0.000707 & $\mathbf{S}$ & 2.029396 & 0.000684 \\
\hline Due to site & $\mathbf{S}$ & 81.8593 & 7.45608 & $\mathbf{S}$ & 4.24194 & 4.67605 \\
\hline
\end{tabular}

Fig.1 $\mathrm{pH}$ and EC $\left(\mathrm{dS} \mathrm{m}^{-1}\right)$ at 0-15 and 15-30 $\mathrm{cm}^{-1 e p t h}$ in farmer's field

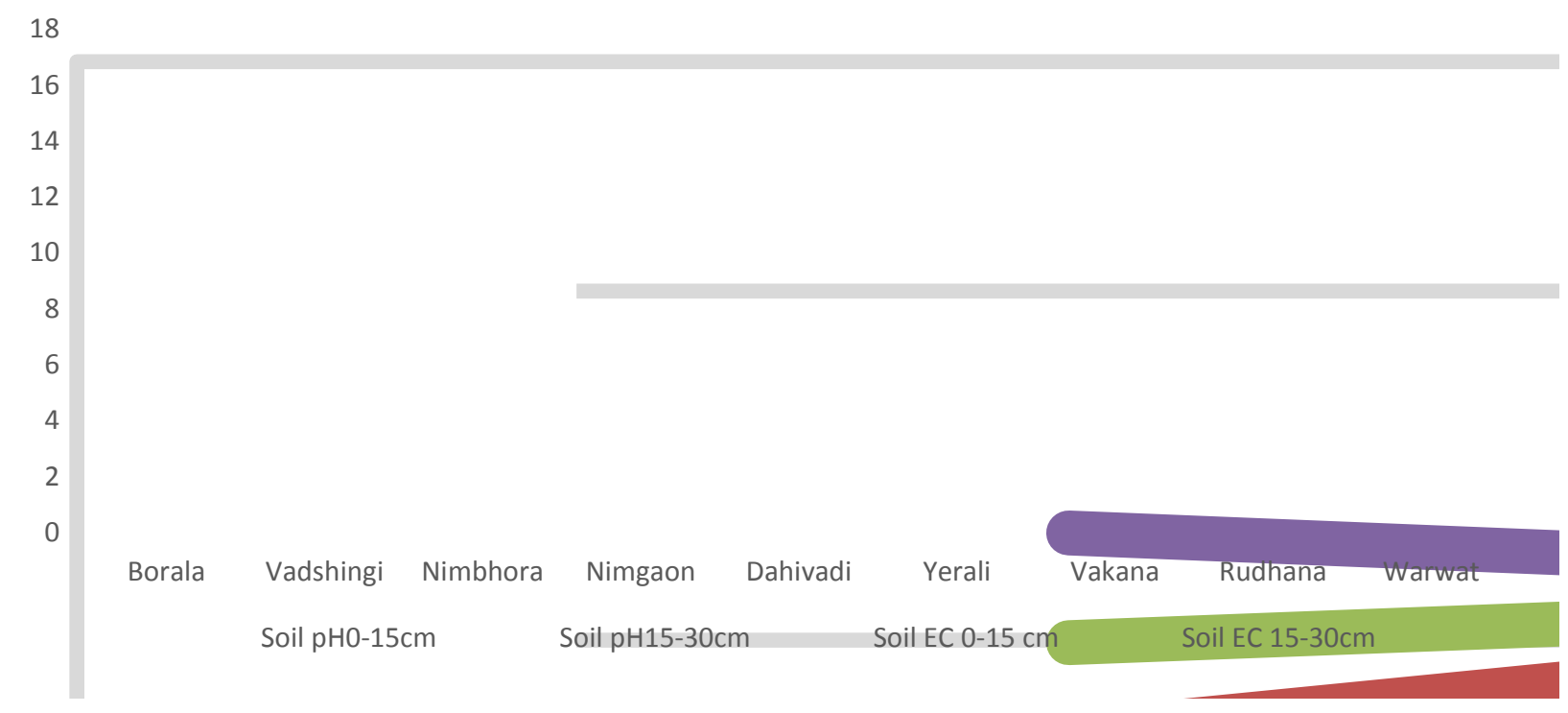


Fig.2 Organic carbon and Organic matter (\%) content at 0-15 and 15-30 cm depth of soil in farmer's field

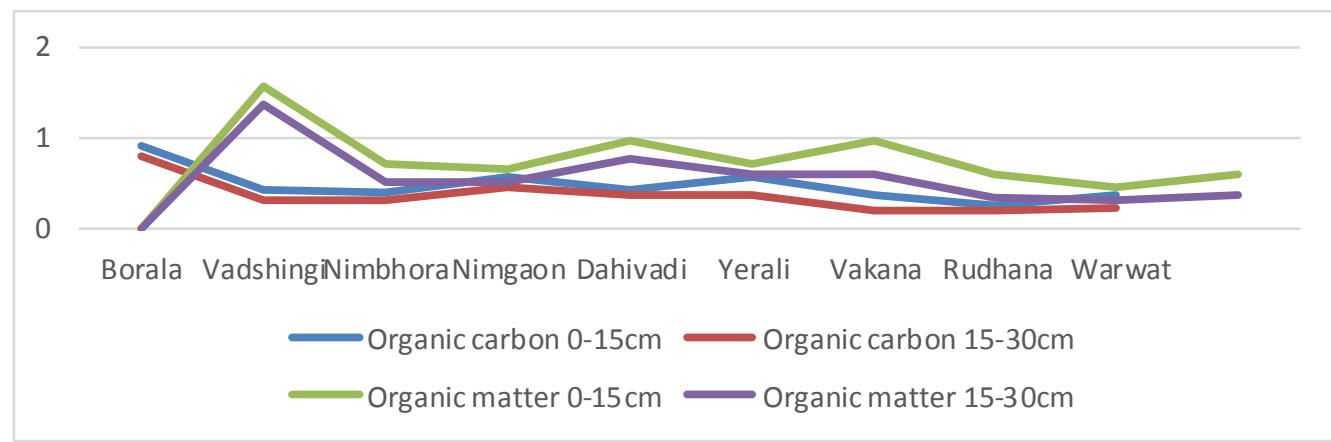

Fig.3 Response of available nitrogen, phosphorus, potassium and calcium $\left(\mathrm{kg} \mathrm{ha}^{-1}\right)$ in farmer's field at 0-15 and 15-30 cm depth

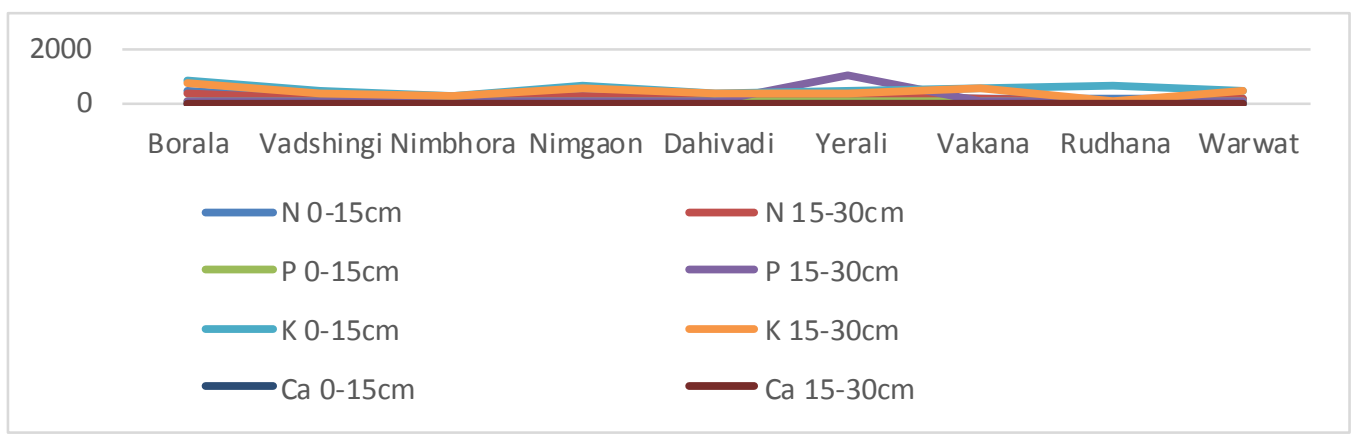

Source: bharatmaps.gov.in

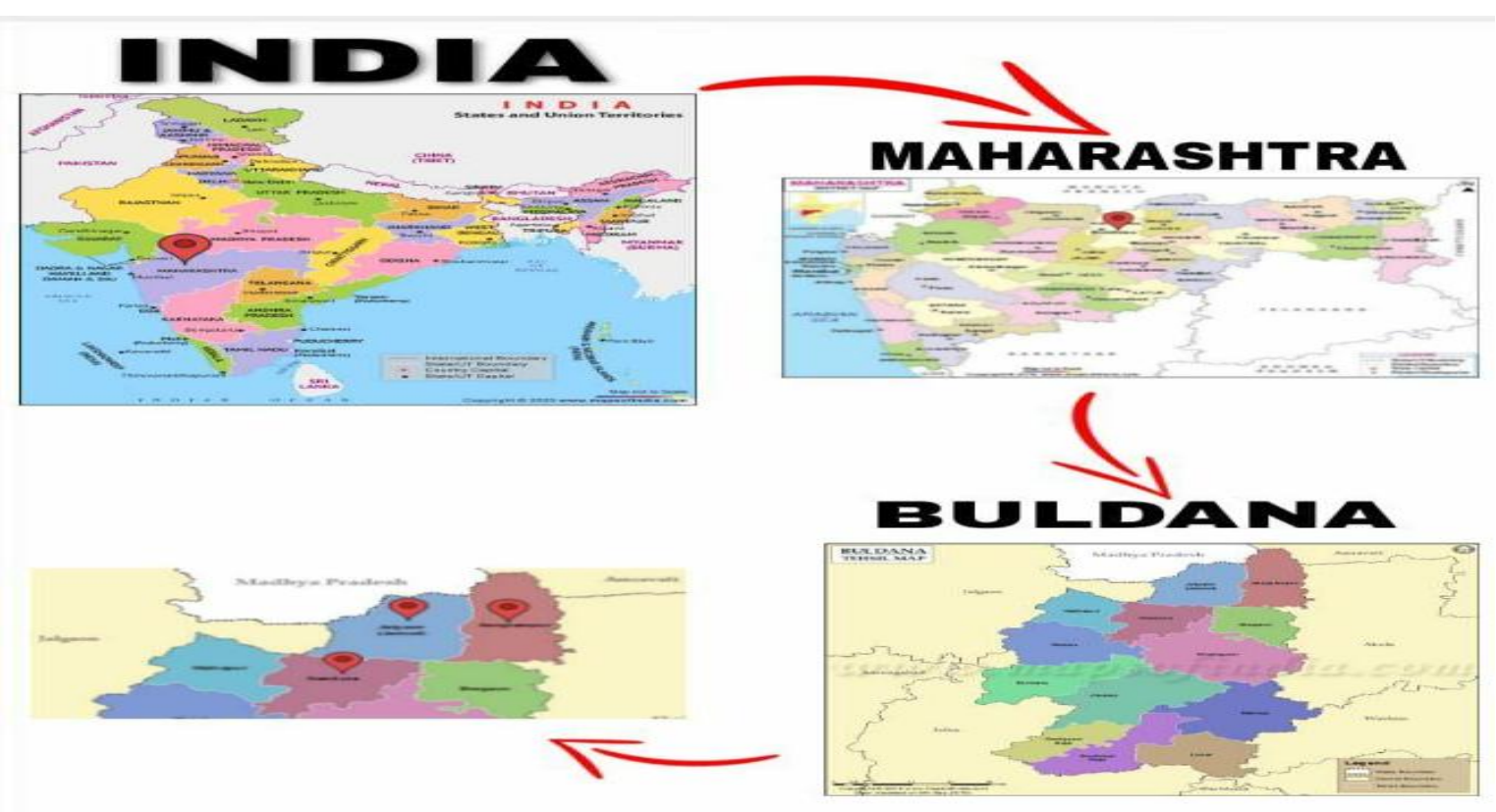


As presented in table 6 and fig. 3, the highest soil available K $493.6<493.8$ lowest 295.6 were recorded in villages Vakana, Warwat and minimum Nimbhora respectively, at 0-15 $\mathrm{cm}$ depth and at $15-30 \mathrm{~cm}$ maximum available nitrogen $442.1<0.45$ lowest 0.18 were recorded Borala, Nimgaon and lowest Rudhana, due to depth and sites and available $\mathrm{K}$ was found to be significant. the high contain of organic matter increase the level of $\mathrm{K}$, Similar results were reported by Upadhyay et al., (2014). and the highest soil available calcium $0.45<0.42$ lowest 0.35 were recorded in villages Nimbhora, Dahivadi and minimum Vadshingi respectively, at $0-15 \mathrm{~cm}$ depth and at $\quad 15-30 \mathrm{~cm}$ maximum available calcium $0.42<0.41$ lowest 0.32 were recorded Nimbhora, Dahivadi and lowest Vadshingi, due to depth and sites available calcium was found to be significant, calcium buildup is caused by excessive use of inorganic fertilizer or the use of composts and manures high in phosphorus. High soil calcium levels also can threaten streams, rivers, lakes and oceans. similar results were reported by Bhise et al., (2019).

It was concluded that soil parameters were studied during the course of investigation responded good soil health the best villages was Borala followed by Nimgaon, block Buldana of Maharashtra. It was found the $\mathrm{pH}$ slight acidic to neutral, EC, Nitrogen, Organic carbon, Potassium and Phosphorus in adequate range having good amount of $\mathrm{Ca}$ $\mathrm{Mg}$. The available nutrients are based on farmers applied sources such as fertilizers, organics manures, crop residues, biofertilizers, etc. in their field for respective crops. The findings of the results are based for Buldana Block of Maharashtra were suitable for cultivation of such as cotton, maize, redgram, gram and soyabean etc., and soil having good fertility status and productivity.

\section{Acknowledgement}

I am grateful for ever-inspiring guidance, constant encouragement and scholarly comments and constructive suggestions throughout the course of my studies and investigation, from, head of the department and staff, Department of Soil Science and Agricultural Chemistry, Sam Higginbottom University of Agriculture, Technology and Sciences, Prayagraj, Uttar Pradesh.

\section{References}

Brij M. Upreti et al., (2016). Worked upon Physiochemical Characterization of Soil Collected from Sacred and Non-Sacred Forests of Uttarakhand characteristics of major shrink-swell soils of Jalgaon district, Maharashtra, India.

Bhise, M., Nadeemashaban, and Rishapaul, M. (2019) Physico-chemical properties of soil Kusmunda area district Kobra (Chattisgarh), Indian Journal of Pharmaceutical Science and Research 4(3): 139-143.

Dhamak, N. A. Meshram and S. L. Waikar., (2015). Evaluation of nitrogen fractionation in relation to physicochemical properties of soil in Ambajogai Tahsil of Beed District. IOSR Journal of Agriculture and Veterinary Science (IOSRJAVS),7(12):81-85.

Ganorkar R. P., P.G. Chinchmalatpure (2013) Physicochemical Assessment of Soil in Rajura Bazar in Amravati District of Maharashtra (India). International Journal of Chemical, Environmental and Pharmaceutical Research. 4(2\&3): 46-49.

Jackson, M. L., (1958). Soil chemical analysis. $2^{\text {nd }}$ edition, Indian Reprint, Prentice Hall of India, New Delhi, p. 498.

Muthuvel, P., Udayasoorian, C., Natesan, R., 
Ramaswami, P. R. (1992). Introduction to Soil Analysis. Tamil Nadu Agricultural University, Coimbatore, 1992.

Munsell, A. H. Munsell Soil Color Charts. Munsell Color Company Inc., Baltimore, 1954.

Olsen, S.R., Cole, C.V., Watanhe, F. S., and Dean, L. A., (1954) Estimation of available phosphorus in soils by extraction with sodium bicarbonate. U.S. Deptt. Agr. Circ., 939.

Papendick and Parr, (1992). Gave soil degradative or conserving processes and is controlled by chemical, physical and biological components of a soil and their interaction. Panjabrao Deshmukh Krishi Vidyapeeth, Akola. Agropedology., 25(01): 43-53.

Priyanka AV, Guldekar VD, and Ghabane VV, (2018). Assessment of available soil nutrient status in black soils of Akola district, Maharashtra. Journal of Pharmacognosy and Phytochemistry 2018; 7(5): 1124-1129.

Subbaiah, B. V. and Asija, C. L. (1956). A Rapid Procedure of the estimation of available nitrogen in soils. Curr.
Science. 25: 259-260.

Tale, S and Ingole, S (2015). Worked on the role of phsico-chemical properties in soil quality An understanding of physical and chemical condition of any soil is essential for proper implementation of the other management practice.

Toth, S.J., and Prince, A. L., (1949). Estimation of cation exchange capacity and exchangeable $\mathrm{Ca}, \mathrm{K}$ and $\mathrm{Na}$ content of soil by flame photometer technique. Soil Science. 67: 439-445.

Upadhyay, M. and Dhruv, V. (2014) Studied on soil profile and chemical analysis of soil Chhattisgarh with special reference to Kurud Block of Dhamtari District, Journal of Pharmaceutical Biology, 4(1): 12-15.

Wilcox, L. V. (1950). Electrical conductivity. Am. Water Works Assoc. J. 42: 775-776.

Walkely, A., and Black, I. A. (1947). Critical examination of rapid method for determining organic carbon in soils, effect of variance in digestion conditions and of inorganic soil constituents. Soil Science. 63: 251-257.

\section{How to cite this article:}

Panherkar Ujjwal, Tarence Thomas and Arun A. David. 2020. Assessment of Chemical Properties of Soil from Different Blocks of Buldana District Maharashtra. Int.J.Curr.Microbiol.App.Sci. 9(11): 3002-3010. doi: https://doi.org/10.20546/ijcmas.2020.911.363 